\title{
Rewards and punishments as developing gendered ideologies in Grimm Brothers' Briar Rose
}

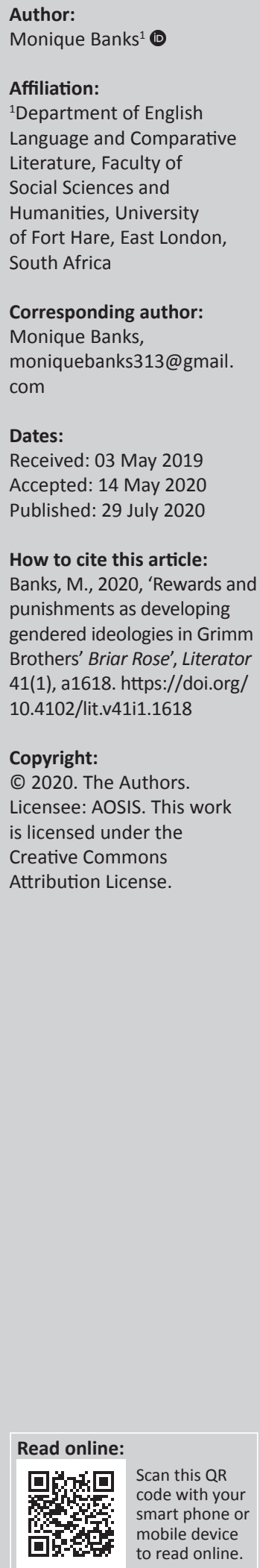

Fairy tale literature can be identified as didactic, as it shares moralistic and educational ideals through its characters and themes. Intending to instruct, fairy tales relate specific moralistic concepts, indicating accepted and unaccepted conduct. Researchers have postulated the correlation between a fairy tale and its social context, considering that these tales include contrived elements specific to the societal structure from which they originate. Specific to this research is the connection between a fairy tale and the gendered ideals held within the society as noted in Grimm Brothers' Briar Rose. The version analysed in this article is the Collins Classics collection of the Grimm Brothers' tales, which was published in 2013. This tale reflects content which perpetuates and supports the patriarchal expectations of the 19th-century Germany. The Grimm Brothers' treatment of the princess, 13th fairy and prince reinforce gender-specific roles for men and women. The rewards and punishments earned by the characters mould not only their behaviours, but also potentially the behaviours of the 19thcentury readers. This article analyses the behavioural consequences faced by the characters in Briar Rose, with particular consideration of how these responses convey gender ideals to the readers, and how these influence their own subsequent behaviour and expectations.

Keywords: the Grimm Brothers; Briar Rose; fairy tale; gender ideal; 19th-century literature; patriarchy; gender roles; reward; punishment.

\section{Introduction}

The Grimm Brothers' collections of tales were compiled because the brothers believed their country needed a single language, set of beliefs and culture. They, therefore, sought to develop a literature which would embody these (Haase 2008:408). This prompted the brothers to seek ways to preserve the folk tales told within their society, and so, in 1812, they published a collection of tales called Kinder- und Hausmärchen [Children's and Household Tales 1812]. They then republished this original collection with an additional 70 stories in 1815 under the same title (Jean 2007; Meyer 2015). The Grimm Brothers maintained that their tales were inherently German: that they were originally oral tales passed down through generations, and that some tales within their collection originated in oral form over 300 years prior to their publication (Smith 2013:105). The tales' origin in German history leads them to be seen as 'important representations of German literature' (Robinson 2010:1), which has increased the popularity of the tales. The brothers' research into the oral tales shared within their society and their subsequent publications represented the scope of life experience in 19th-century Germany. Zipes (1987:107) highlights that popular tales are those that stick to the characteristics expected of a society. Furthermore, tales which deviated from and created alternative ideas to the rigid societal structure struggled to be accepted by readers and, therefore, society. France in the 17th and 18th centuries highlights a great example as Ebel (n.d.) mentions female authors, such as Madame d'Aulnoy, Madame l'Heritier and Madame du Murat whose tales did not receive the same recognition as the more well-known tales by Charles Perrault. These female writers are unrecognisable by most people, even in today's society; however, Perrault and his tales are much more popular. Ebel further states that next to Perrault, CharlesJoseph Mayer and the Grimm Brothers are celebrated for the development of folk tale heritage and the women writers of earlier centuries have been wiped out of the history.

Although the Grimm Brothers' tale is analysed within this article, their collection was not the first of its kind. The brothers published their tales as remakes of stories previously told. The tales stem from a long history of stories passed down through generations. Popular writer Charles Perrault's collections of tales include stories similar to those of the Grimm Brothers. However, writing for a different, more adult audience, Perrault's tales are much more gruesome than the watered-down versions made by the Grimm Brothers. Perrault's Briar Rose equivalent, The Sleeping Beauty in the Woods, for example, includes a Sleeping Beauty who is passive and accepting of her situation, 
even when her prince leaves her in a castle for 2 years to hide her from his family. There is a familiar, vindictive fairy who casts a spell upon the princess. The prince hides his marriage to the princess and for 2 years she remains in the castle where she slept, in which time he visits sporadically and she bears him two children. The tale also includes an ogre - the prince's own mother who, upon meeting Sleeping Beauty, attempts to eat her and the two children. Luckily, the prince saves his family before they can be devoured by the ogress, but not before he pushes his mother into a pit of toads, vipers and serpents. Although the tale differs from the Grimm Brothers', it is important to note its existence as an earlier text and its influence on the Briar Rose written by the Grimm Brothers.

The brothers' ability to integrate 19th-century German sociocultural ideas into their tales made for very successful collections. Their tales, therefore, had an immense influence on their readership. These readers - young boys and girls who read or were read the tales during this century - were presented with particular ideas. Specifically, the brothers' works illustrated appropriate, societal gender-specific behaviours. Given their profound influence upon society, the Grimm Brothers' collections established boundaries of what was acceptable, or unacceptable for their society. Through the rewards presented to and punishments levied upon the characters, the tales clearly underline what the 19th-century men and women should and should not do. Conformity to these gender regulations was key. Hernandez (2019) asserts that the Grimm Brothers did not intend for their stories to become purely folklore and rather created their collection for scholars of German culture. However, Hernandez further explains that although it was not their intention, the tales soon became celebrated folklore and he calls them 'childhood defining' and popular children's tales. The young 19thcentury readers of the Grimm Brothers' tales were influenced by their content (Karpman 2011), encouraging desired behaviour leading to rewards, and avoiding undesired behaviour which might result in punishments.

The didactic quality of literature found within the Grimms' works can be identified in a number of works published prior to the Grimm Brothers' tales. Medieval and early-modern writers enforced the importance of constant reminders... advice relevant to particular situations... [and the] creation of goodness and knowledge of right living' (ed. Ruys 2008:2). This created a plethora of advice literature which aimed at informing its reader throughout several topics: social, religious, pedagogical and many more (ed. Ruys 2008). Plays such as Dr Faustus by Christopher Marlowe emphasise the importance of morality and ensure an understanding of right and wrong is developed within its tale. Literature aimed at educating men and women about gender roles is also longstanding and included notes on how men and women are expected to behave within the medieval and earlymodern societies (eds. Bennett \& Karras 2013). Although created in earlier times, this literature's influence can be seen in Grimm Brothers' work as they too strive to educate their readers and inform them about correct conduct and morals.
The Grimm Brothers' tales have long since been identified as tales which subscribe to typical, patriarchal gender expectations. Hoffert (2003:ix) emphasises that fairy tales include the cluster of characteristics, behaviour patterns, and values that members of a group think a man or a woman should have, a set of cultural expectations'. These expectations and gendered ideas, however, stem from the larger society in which the text is written and when they are read within texts, gendered ideas are further entrenched and strengthened. Appell (2012) discussed the Victorian era's ideas of gender and stated that women were taught the basic tasks of 'feminine duties... weaving, cooking, washing, and cleaning' and were not expected to be educated outside of the home as it was a 'man's world'. This continued into the 19th-century society, where the belief was that the private sphere, and out of the public sphere, was the place where women were of most use to their husbands and families (Sagarra 2009:407).

In 19th-century Germany, women were expected to be beautiful, submissive, passive, controlled and silent caregivers in their homes. They were also to be endowed with beauty and virtue and seeking marriage to a handsome man (Kuykendal \& Strum 2007; Rowe 1986; Sawyer 2014; Zipes 1987). Parsons (2004) states that fairy tales 'are an integral part of the complex layering of cultural stories and influences that affirm and perpetuate cultural norms' and continues that:

$[A]$ primary goal of gender construction in patriarchal culture is to prepare young girls for romantic love and heterosexual practices. Girls come to know that their value lies in men's desire for them. (pp. 135-136)

In this case, the Grimm Brothers' tales affirmed the cultural norms of their society - and influenced their young 19thcentury readers - through the systematic use of rewards and punishments allocated to behaviours of the characters.

Nineteenth-century women were also to be innocent and feminine in order to make them acceptable for marriage 'for by that alone was it possible for a woman to rise in the world' (Petrie 2000:180). Women were to spend many years preparing for marriage, because 'if a man or woman did not possess the qualities desired by the Victorian society, the opposite sex may have dismissed the person as an unsuitable mate' (Appell 2012). Marriage was undoubtedly the happy ending each woman was expected to desire and, if they were to obtain it, they would first need to meet the society's gendered requirements. Altick (1973) elaborates that:

A woman was inferior to a man in all ways except the unique one that counted most [to a man]: her femininity. Her place was in the home, on a veritable pedestal if one could be afforded, and emphatically not in the world of affairs. (p. 54)

The characteristics of a compliant 19th-century woman, as outlined above, further point to her having limited access to the same possibilities for independent social advancement as men would have. Paradiz (2005) stresses the lack of autonomy and the lower ranking of women, as these women spent their 
lives under the control of men. Firstly, they were under the rule of their fathers and once married off would be placed under the control of their husbands. Fairy tales often conform to this, as female protagonists are commonly confined to high towers or castles, making them naïve to the outside world.

Considering the profound influence of the notion of 'happily ever after' exhibited in the fairy tale genre, marriage is viewed as the ultimate reward (Zipes 2006:40-41). This is evident in the fairy tales penned by Charles Perrault and perpetuated in the tales written by the Grimm Brothers: all of which illustrated that one's most important goal should be finding a significant other of the opposite gender (Zipes 2006:42). The rewards for appropriate gender behaviour of princess characters in Grimm Brothers' tales are almost always marriage. For example, the tale of Rapunzel ends with the statement: ' $[h] \mathrm{e}$ led her to his kingdom where he was joyfully received, and they lived for a long time afterwards, happy and contented' (Brothers Grimm 2013b:75). After the young Rapunzel patiently waited for her prince to save her, she was rewarded with a 'happily ever after'. Moreover, this line further highlights that the masculine, heroic prince has control over the princess and she submits to his guidance as he leads her to his kingdom. Similarly, Snow White marries the handsome prince and, nearing the end of the tale, the prince remarks: 'I love you far better than all the world; so come with me to my father's palace, and you shall be my wife' (Brothers Grimm 2013c:149). Snow White's prince leads her to his palace and takes her as his wife. The young girl becomes his after he rescued her from the spell-cast sleep. This echoes the Victorian sentiments of marriage, which encourage that women are the property of their husbands. In the same manner, Ashputtel - more commonly known as Cinderella - meets her happy ending by marrying a prince, as is seen in this statement: '[a]nd when he drew near and looked at her face he knew her and said: This is the right bride' (Brothers Grimm 2013d:171). Again, the prince is active in his decision to marry the young maiden and he resolves that she will be his bride, with no concern of Ashputtel's opinions. Rapunzel, Snow White and Ashputtel all resemble feminine characteristics of submission, dependence and passivity and so the heroic princes come to save and marry them.

These tales, and many more, depict marriage as the happiest outcome for women. A woman's success seems enmeshed with married life, most especially one which involves a handsome prince. Succinctly, beautiful maidens are married to handsome men, and heroic princes marry submissive princesses. These marriages also only occur after the princesses and princes have represented themselves in typically century-specific gendered ways, as was traditional in that era. Only beautiful, submissive, docile girls marry the courageous, resourceful, handsome princes. If marriage is the reward, then loneliness, isolation and abandonment are punishments. When the 19th-century women do not fulfil the expectations of beauty or do not behave in typically feminine ways, they are denied the opportunity to marry. Ashputtel (2013d) includes two young female characters described as 'foul at heart' (Brothers Grimm 2013d:164) and unpleasant who want to marry the handsome prince. However, it is the soft-hearted 'good' (Brothers Grimm 2013d:164) Ashputtel who attracts the prince to such an extent that he takes on a quest to find and marry her. Emphasising the typical fairy tale structure, the deceitful sisters are denied a happy ending with the prince and in their place; Ashputtel receives her reward: a handsome prince. Therefore, the tales closely mirror the expectations set out by the 19th-century Germany with regard to the society's expectations about women and marriage. In discussing the typical female characters in their tales, light is also shed on the limitations placed on women in the 19th century. Zipes (2012:4) maintains that 'stories not only contribute to the making of our narrative selves but also weave the threads of social relationships and make life social'. However, texts and society have a reciprocal relationship, and not only are texts influenced by society, but society and its readers are also influenced by the texts they read.

The 19th century also included particular gender expectations for men, which ensured that they behaved in particular ways. They were required to be powerful, dominant and courageous financial heads of their households (Kuykendal \& Strum 2007; Parsons 2004:137; Rowe 1986; Sawyer 2014; Zipes 1987). These characteristics were closely related to masculinity and were defined as the actions of real men of the age. Within tales, Gregor (1985:209) states that characteristics such as 'action, physical strength, courage, [and] loyalty' are assigned to heroic male characters throughout fairy tale literature. Mechling (2011:31-32) emphasises the importance of a man's 'good character' and 'meet[ing] his responsibilities to family, work and nation'. Furthermore, princes and other successful male characters in Grimm Brothers' tales are handsome, gallant, caring and independent. Mechling (2011:32) also highlights that wealth is a common reward for conforming characters: 'the man who practices the social and moral virtues, will enjoy tangible and intangible wealth'. Andrew Tolson (in Brittain 1989:84) confirms that economic triumph and the ability to work hard and achieve success are important components of the masculinity required by male characters. In one way or another, a male character's life can be altered if he adheres to the prescribed masculine traits. Chakravorty (2013:265) counters such presentations of masculinity by stating that 'if some man does not do anything to live up to that image... then they too are subject to the criticisms and castigations of society'. Dolan (2003:15) comments on the roles expected of men, stating that one of the important aspects of masculinity was the ability to control women, and 'shaming rituals' were conducted in which men were harassed for their inability to control an over-powering woman. Acting outside of the expected masculine characteristics of society results in the punishment of a male. However, 'classic' tales (Zipes 1987:107) do not include male characters which deviate from their masculine characteristics. Princes and other men in tales are heroic, fearless and seek quests, whilst it is only older men who are weaker or fearful. This is seen in Briar Rose as an old man tried to stop the young prince from entering the thicket of 
thorns to save the prince (Brothers Grimm 2013a:30-31). The old man is weary of and frightened by the tales of those who have died before, whereas the young prince is emboldened and full of courage.

Previous writers included the typical expectations of their societies in their tales and discussed how they perceived men and women should behave. For example, Charles Perrault, a writer of the 17th century, published a number of didactic tales which encouraged 'correct', moral behaviour for men and women. Feminine female characters and masculine male characters have been identified throughout his Tales of Mother Goose. Kuykendal and Strum (2007:39) emphasise the gendered nature of Perrault's tales and highlight their patriarchal content. Although they were written within the context of a century that predates the Grimm Brothers' tales, the influence of Perrault's texts cannot be overlooked as they most definitely would have influenced the brothers' works. Cavendish (2012) emphasises the difference between these earlier texts and those penned by the Grimm Brothers. Where Perault wrote for 'sophisticated aristocratic families' (Cavendish 2012:1), the Brothers geared their tales towards developing a common understanding of the culture, values and beliefs of all German people. Their tales include gendered, educational instruction of their society's expected morals, values and behaviours. The eventual assimilation of their well-known tales into the 19th-century schooling system provided the tales the opportunity to have an even greater influence on younger readers.

\section{The tale of Briar Rose}

\section{Briar Rose}

In Grimm's version of 'Sleeping Beauty', the heroine, Briar Rose, is faced with many behaviour-regulating punishments and rewards throughout the tale. When she acts according to social expectation, she is rewarded with happiness and peace; however, when she embodies any masculine traits such as independence and power, or when her behaviour seems to push society's boundaries of preconceived feminine expectations, she is punished with a 100 year sleep. The significance of her beauty and feminine nature is emphasised throughout the tale. The Grimm Brothers describe her as 'beautiful, and well-behaved ... good, and wise' (Brothers Grimm 2013a:29), and as such is loved by everyone. Hence, it is her ability to portray acceptable female qualities that lead to her loveable nature. She is loved only because of how she portrays herself, emphasising the 'correlation between a loveable face and a loveable character' (Lieberman 1972:385). This leaves one wondering whether she would be as loved by so many, if she was not so adorably feminine. She is accepted by her society because she conforms to the expected traits of a 19th-century woman.

Interestingly, Briar Rose is described as wise amongst a number of feminine characteristics. The notion of a female protagonist as possessing intelligence in a tale which is filled with patriarchal content seems to be quite a modern idea. However, as this is a male-authored text, the young girl's wisdom is male-prescribed and enforces masculine-ordered values. Briar Rose behaves within acceptable, patriarchal expectations and norms; therefore, her abiding to gender expectations leads to her wisdom. Her wisdom arises from her gendered behaviour.

The curse is finally fulfilled and the happiness in the tale is disrupted when the princess is 15 years old. The events leading up to the curse begin with Briar Rose's father who does not invite all the fairies to the gathering, and although the 13th fairy's curse is what causes the sleep, Briar Rose's actions also play a role in initiating the curse and causing her punishment. It is her curiosity and lack of submissiveness which results in her punishment of a 100-year sleep. Curiosity is said to be an undesirable characteristic, as emphasised by Thiselton-Dyer (2014:130) first published in 1906: '[b]oth history and social romance afford many a striking instance of the dangerous and fatal effects of over-inquisitiveness'. In the build-up to this event, the young princess, instead of remaining in her confined space, wanders outside those boundaries on her own and stumbles upon a tower room where she discovers an elderly woman spinning. She speaks her first words of the tale to this elderly woman and, being apparently confident and inquisitive, asks: '[w]hat are you doing there? ... How prettily that little thing turns round!' (Brothers Grimm 2013a:31). She then takes the spindle from the old woman, attempting to spin herself. Curiosity 'reflects a legitimate desire not to remain ignorant' (Pellegrin 2016:160); it is an active act rather than a passive behaviour. These actions go against the passivity expected of women, as independent action and inquisitiveness were forbidden for women in the 19th century. Briar Rose's actions here do not resemble the previously discussed 19th-century feminine ideals of the dutiful princess. Weitz and Kwan (2014) maintain that the 19th century was a time when patriarchy and gender stereotypes projected women's behaviour as submissive, obedient and to remain happily ignorant: characteristics marked out for a good wife. Women were not to act independently or aggressively but work quietly in the home, drawing very little attention to themselves. The princess's actions here may be attributed to her defiance of these qualities. Through her curious, independent actions, the princess has clearly acted against the societal expectations of a woman and so she is punished for it. She pricks her finger and activates the spell cast upon her, succumbing to a motionless, silent sleep for 100 years. Interestingly, the rest of the court also falls asleep with Briar Rose and together the whole castle sleeps through the 100-year curse. Briar Rose's incorrect behaviour - according to the 19th-century expectations - is the reason for not only her punishment, but the court's as well. This could be a comment on the negative impact that female disobedience has on a particular society. Ultimately, the idea conveyed is that, if a woman does not act in line with what is expected of her, she will be punished, and will thereby inflict hardship on those around her as well.

Whilst in this sleeping state, she is endlessly beautiful, passive and completely submissive, embodying the expectations of her gender (Kuykendal \& Strum 2007; Rowe 1986; Zipes 1987). News spreads around the kingdom and 
she is described as the 'beautiful sleeping Briar Rose', 'a wonderful princess' who lays asleep in the castle along with her court. The princess is rewarded 100 years later for her acceptable behaviour; the handsome prince rescues her from her cursed sleep with a kiss. Chakraborty (2019:59) emphasises this 'rescue', discussing the princess's submissive nature in waiting patiently for her hero. Interestingly, once she awakes, her behaviour is different. When she meets the prince, she is elegant and loving. The princess does not speak at all when she meets the prince and so she remains a silent beauty. It is as if she has learnt that speaking out of turn and acting independently are not desirable and must be avoided if she is to be rewarded with her 'happily ever after'. Furthermore, it is her beauty which compels the prince to kiss her and finally break the spell as this statement illustrates: '[s] he looked so beautiful that he could not take his eyes off her' (Brothers Grimm 2013a:31). Berger (1972:47) states that a woman's role within society is to be viewed or observed, so she is reduced to an 'object'. Importance lies in her physical body pleasing the male observer 'because how she appears to others, and ultimately how she appears to men, is of crucial importance for what is normally thought of as the success of her life' (Berger 1972:46).

Discussing 'The Little Mermaid' by Hans Christian Anderson, Heyn (1992:89-90) maintains that the fairy tale teaches a number of 'love lessons' which can also be found in Grimm Brothers' Briar Rose. Firstly, 'if he [the prince, or hero] does not recognize who he is seeing, or if he doesn't like what he sees, you [the princess] are in danger of ceasing to exist' (Heyn 1992:90). Beauty is hugely important for Briar Rose, because, without it, the prince would not have sought out or woken her. Physically, she pleases him, which means that she must be rewarded for complying with the standard established for her gender's appearance. Secondly, Heyn highlights the emphasis that many tales place on women staying 'gracious, silent, selfless and forgiving' no matter their circumstances, and, if these characteristics are maintained, a young princess will be seen as 'good' and thus worthy of marriage. Briar Rose's ability to wake up with grace and remain silent without complaining of her lot has afforded her the reward of marriage, which is often expressed as a happy ending in these tales. Although she has just spent many years in sleeping and being motionless, Briar Rose neither complains about nor comments on her suffering. She only smiles deferentially in greeting her prince: happy that he has finally arrived to rescue her. Her significance in the tale is limited to her incredible physical beauty and suffering because of her curiosity, a symbol of her naivety. The male-authored text therefore illustrates the consequence of such curiosity and actions. Finally, the princess's liberation from her suffering comes through the prince's intervention: typical patriarchal expectations. Smith (2013:106) maintains that 'pure, virtuous girls who suffer in silence are rewarded' and, in Briar Rose's case, she is provided with a husband.

The rewards and punishments received by the princess throughout the tale not only socialise the behaviour of the princess, but also that of the 19th-century female reader. Lieberman (1986) comments that:

[T] he child who dreams of being a Cinderella [or any princess for that matter] dreams perforce not only of being chosen and elevated by a prince but also of being a glamorous sufferer or victim. (p. 194)

Parsons (2004) also enforces that fairy tales convey a message that:

$[W]$ omen must suffer, if not be humiliated, before they are rewarded... being rewarded with the prince and the security of marriage is the result of the heroine's submission and suffering, along with her beauty. (p. 137)

The young 19th-century female reader yearns for the rewards provided to the princess, and so she makes sure to mould her thoughts and behaviours according to those of the princess. The reader acknowledges that, in order to receive her happy ending, she must first be 'tested' and endure treacherous circumstances patiently. If she does this, she is assured, through the tales of fairy princesses, that a prince will find her and enable her fulfilment.

Moreover, just as the princess does not act in masculine, domineering, aggressive ways after waking and meeting her prince, the 19th-century female reader is introduced to the idea that behaving according to patriarchal expectations will lead to happy endings. The tale promotes that the female reader should be quiet and submissive, thereby adopting the expectations of the society in which she lives. She learns not to question her situation and to suffer through any difficulties encountered in order to receive the patriarchal rewards she is convinced she must have. Finally, this is not to suggest that a tale needs a defiant, 'masculinised' female to be contemporary, nor that all tales which represent women as housewives who are eager to marry and bear children - are patriarchal and must be challenged. However Briar Rose resembles the submissive, passive, controlled and obedient princesses of many of the Grimms' 'classic tales' as defined by Zipes (1987:107). As Chakraborty (2019:59) states, 'the feminist concern here [within these tales] is the notion of a young woman's sacrifice for single, unified, romantic goal'. The collection, including 'Briar Rose', represents the importance of female submissiveness and patience when women face problems. Only through behaving in these ways can women obtain their 'goal', or at least what these tales claim should be their goals: happy marriages to handsome men. In including these female characters, the Grimm Brothers restrict the possibilities for a female reader in the 19th century to encounter an independent, powerful and heroic female protagonist, therefore dissuading her from behaving in more contemporary ways.

\section{The 13th fairy}

Where the Grimm Brothers represent Briar Rose as obedient, docile and accepting of her terrible circumstances, they also represent her antagonist as one who defies what is expected of a submissive and passive 19th-century woman. 
The 13th fairy forces her way into the king's great feast, even though she has not been invited. She is angry and defiant against the king's decision to exclude her from the festivities and seeks 'to take her revenge' (Brothers Grimm 2013a:29). Unlike the princess, this fairy reacts to the wrong done to her and is proactive in showing those around her that she will not take this lightly. Her forcefulness and rebellion against patriarchal authority are not typical feminine characteristics and are rather contradictory to the expected behaviour of the 19th-century women. Moreover, the fairy's malevolent intentions further her in contrast to the princess. While Briar Rose is 'well behaved, and good' (Brothers Grimm 2013a:29), she is evil and spiteful, casting a spell on the princess to destroy her happiness. Indicative of her aggressive, masculinised manner, the evil fairy is represented as different from other fairies. Dressed in their red caps, red high heel shoes and white wands, the 12 fairies at the feast are also called 'friendly fairies' (Brothers Grimm 2013a:29). However, the 'evil' (Brothers Grimm 2013a:29) 13th fairy is dressed in a black cap and shoes and is carrying a broomstick, resembling an archetypal witch character.

According to Neikirk (2009:38-39), these kinds of contrasting characters are greeted with suspicion by both characters and readers alike. In general, they bring about disaster to the tale, and interfere with and try to prevent the protagonist from achieving a 'happily ever after'. In many cases, their upsetting behaviour and abrasive personality lead to further loneliness, isolation and, very often, death. This is seen throughout a number of the Grimm Brothers' tales. The envious queen in Snow Drop (Brothers Grimm 2013c:146) turns herself into an 'old woman', and, in an act to kill the beautiful girl, uses this disguise to gain Snow Drop's trust. She uses a poisoned comb on Snow Drop's hair, who falls down unconscious. She does not succeed in her plot, however, and is punished by having to stand in heated iron shoes and dance until her death. Hansel and Gretel (Brothers Grimm 2013e:93) includes a frightening 'wicked old witch', who hobbles when she walks with her crutch, and who plans to eat the two young children. She also meets her end because of her wicked ways when she is pushed into the same fire in which she wishes to roast Gretel. In the same way, the 13th fairy's physical appearance sets her apart from the other fairies and the princess. Her hostile behaviour and insistence on casting a spell on the princess ensure that the tale's happiness is interrupted. Although she is not outwardly punished or killed, her seclusion from the gathering conveys a similar message as the princess's: those who do not conform to the gender ideals of women will be isolated. They face seclusion and ill-fortune if they choose to follow this path: a fairy tale consequence which reinforces the importance of the 19th-century female readers' co-operation with the patriarchal society's gender roles.

These characters' inclusion in the tale leads to a maleauthored rejection of such empowered, active, patriarchycontrasting women. This is done in a way which ensures the 19th-century reader's understanding that such feminist thought leads to punishment and rejection, and so it should be avoided. The fairy not only causes unhappiness in the tale but actively questions patriarchal gender expectations. She is a feminist intrusion into a strongly patriarchal tale and on the 19th-century society as a whole. Diverging from the 19th century's gendered expectations of women, it is clear that deviant, patriarchy-contrasting women like the fairy will never receive the same rewards as the rule-abiding princesses and young heroines. Moreover, they must endure rejection in the tale, and in the 19th-century reader's society as well.

The 13th fairy soon becomes an unlikeable character because of her behaviour and the evil spell she casts. Although the king attempts to avoid the curse and rescue his helpless, cursed daughter, even his noble power is unable to save her. This defiant female character who behaves outside of the expected submissiveness, silence and patriarchal society's control single-handedly disrupts the tale's happiness. The 13th fairy suggests to the reader the negative consequences possible when females act outside of their patriarchally prescribed gender roles. They cause disaster in the lives of men, women and an entire kingdom. Thus, such actions should be avoided and castigated by the 19th-century women readers to ensure cooperation.

The punishment provided to Briar Rose and the 13th fairy indicates strict guidelines which should not be crossed: masculine behaviours are not accepted when expressed by females. As the princess behaves in ways unexpected of her gender, such as acting out of turn, she is punished. Moreover, the evil fairy behaves in ways that conflict with gender expectations, and so she is not provided a happy ending or any form of reward. This suggests that it is the female character, and indirectly the female reader, who is in danger of behaving against the society's gender ideologies and suffering the consequences for their aberrations. Female characters are seen as more likely, than male characters, to contest the strict rules set for their gender and challenge patriarchal authority, and so they must be punished or shown punishment, which is harsh enough to prevent them from attempting to rebel.

\section{The prince}

Some of the dominant, masculine traits held by the prince are that he is young, brave and heroic. The height of his masculinity is shown when he pursues his quest to find the princess. A quest is considered to be a 'noble' task (ed. Tatar 1999:31), and so the gallant warrior who attempts one should find honour and receive his ultimate reward. The journey to find Briar Rose is a treacherous one, and the kingdom knows very well of the many princes who have failed in this quest, becoming ensnared and dying in the thorn bushes surrounding the castle. As heroic as he is, the prince is far from deterred by these stories that would put fear in the hearts of most, and he sets out to find the princess, saying: ' $[a] l l$ this shall not frighten me: I will go and see this Briar Rose' (Brothers Grimm 2013a:3). Seeking the quest, regardless of the treacherous odds and danger he knows lie ahead, emphasises the prince's heroism and bravery. Here, it is evident that the prince's quest is motivated by superficial 
reasons. He wishes to see the lovely beauty and it is her physical appearance alone which encourages him to seek her. The princess, according to Berger (1972:47), becomes 'an object of vision: a sight' and is reduced to an object, or property which can be acquired by the prince. Briar Rose is objectified because of her fabled beauty and creates the expectation of happiness only when she can be looked upon and enjoyed.

Briar Rose's diminished feminine power coincides with the emboldened masculine will of the prince. He becomes the hero, by bravely making his way to the thorn bushes without doubt that he will fight his way through them. With no knowledge that the spell has ended, he bravely and nobly enters the bushes as nobody has been able to do before him. The bushes have turned to flowering shrubs now that the curse has completed its course and he enters with ease. Yi (2018:109) discusses the idea that the Grimm Brothers include this ease of access to demonstrate that, in tales where men and women behave in gendered patterns, they are destined for happiness. Just as the princess need not do anything except be attractive in her sleeping state - the prince does not need to face any real hardships to get to his beautiful princess. The prince makes his way around the eerily-quiet castle alone, eventually finding the sleeping Briar Rose. Enchanted by Briar Rose's beauty, he kisses her and awakens her from the prolonged sleep. His success in navigating the deadly thorn bushes allows him to enter the castle and discover the princess. This must surely be his reward for maintaining such overpowering, masculine confidence and bravery. Because the prince has embodied all gendered characteristics expected of him by the patriarchal society, he is rightfully rewarded with a beautiful, young princess who is to marry him and with whom he can start a family.

The princess has already been described by the Grimm Brothers as so beautiful, young and feminine that she becomes quite sought after, not only by the prince but also by the 19th-century reader, whether male or female. Firstly, a female reader would seek to be similar to the princess because she receives the reward of a handsome prince who rescues her. Secondly, a male reader would seek the princess because she is beautiful, passive and accepting. She is the ideal reward for a courageous, masculine prince and the desired reward for the male reader. The reward, of a beautiful wife, provided to the prince shows the male reader that he needs to act in ways which are patriarchally expected if he has to receive the same type of reward. Hence, the young 19th-century male readers are shown the importance of shaping their thoughts and behaviour patterns that are in alignment with those of the heroic prince; he must project masculine traits in his own life in order to receive the same rewards as the prince. Humphrey (2005:xvii) concurs, stating that 'the moral dilemmas the hero faces engage the child in his or her own process of decision-making and resolution of difficulties'. The masculine, powerful, independent, commanding prince shows the male reader that this is how he ought to behave if he has to receive a happy ending. The 19th-century readers are taught by the prince character that men need to act as masculine figures if they are to live happy lives and marry beautiful princesses.

Like the princess, the prince is also rewarded when he follows the gender expectations set out for him. According to the 19th-century expectations for a man, he is to be handsome, young, strong, powerful and in control of himself and those around him. If he can portray these gendered expectations, the prince will receive all he desires; he will be rewarded greatly and live a happy life. Lieberman (1986:188) emphasises this point by stating that, within the fairy tale, 'boys win if they are bold, active and lucky'; all the prince must do is to portray these masculine traits and he will be rewarded.

The responses of male and female readers are encouraged to be quite different through the tale's treatment of its characters. Moreover, male readers are encouraged to behave in brave, masculine ways whereas the female readers are inspired to behave in submissive, feminine ways. Within well-known tales' depictions of male characters, heroics, bravery and control - characteristics of masculinity - are the only possibilities available to men. Hence, fairy tale men are trapped within a particular way of behaving too and are provided no possibilities for acting any differently. In Briar Rose, the prince behaves exactly the way he should, according to the 19th-century gendered expectations, and is generously rewarded for it. The fact that the Grimm Brothers chose not to have their prince - or any male - character punished for some improper actions, is something which runs through their tales. 'Ashenputtel' ('Cinderella'), 'Snow Drop' ('Snow White'), 'Rapunzel' and many other tales include the same theme of masculine protagonists that do not waver in their heroic endeavours. The idea established here is that the prince, or the male reader, is likely to take on the masculine, gender ideals set out for him and so he should not need a harsh punishment to keep him in line. Moreover, his 'correct' masculine behaviour means that the prince is provided with the reward of a beautiful, submissive and quiet princess. Just like the young female characters, the prince character resembles specific traits set out for men.

\section{Conclusion}

The two characters who abide by patriarchally prescribed expectation are handed their final reward at the end of the tale: ' $[a]$ nd then the prince and Briar Rose were married, and the wedding feast was given: and they lived happily together all their lives long' (Brothers Grimm 2013a:31). Their marriage results in the fairy tale happy ending and is the start of a long, contented life together. The final glimpse of the happy couple solidifies a most satisfying and worthwhile outcome. The princess's hardships of the past are forgotten, and she is presented with the happiest life: one which involves a heroic prince. This final scene completes the expectation as constructed within the minds of the 19th-century readers, complete with the promise of their own 'happily ever after'. 
Through the behaviour of their male and female protagonists in Briar Rose, the Grimm Brothers have ensured two things. Firstly, their young 19th-century readers accept the fairy tale marriage between a handsome prince and a beautiful maiden as an ideal state of being. Secondly, these readers govern and assess their own behaviours according to that of the prince and princess in order to embody these characters' personas, and in hopes of eventually being rewarded with the same happy ending. This happy ending, the reader is persuaded, can only be truly met through a wedding between a handsome prince and beautiful maiden.

The Grimm Brothers used their collection of tales to enforce the importance of abiding to patriarchal rule and expectation, enforcing a set of beliefs and unifying set of cultural mores for their own society through collecting and reworking German folk tales. The rewards and punishments experienced by Briar Rose's characters create a unified understanding within their readers: that societal acceptance comes with abiding by societal expectations of what the ideal 19th-century masculinity and femininity should encompass.

These influences are widespread and impact the readers' behaviours in their everyday lives. It is essential to bring these influences to light so as to make the modern readers aware of how they may be impacted in reading an older tale. Today, gender representation has become a point of interest for contemporary scholars, based on rising interest in feminine empowerment, gender equality and gender freedom. It becomes important, then, to shed light on the sociocultural products - such as the fairy tale - which continue to promote patriarchal ideas. Briar Rose, by the Grimm Brothers, is a widely recognised tale and is still read and shared by many today. Identifying its influences, through character rewards and punishments, allows the modern readers the chance to resist the tale's inherent ideas of gender inequality, and to assert more liberal ideas of gender freedom beyond prescribed expectations.

\section{Acknowledgements}

The author would like to thank her supervisor, Prof. Dianne Shober, for her guidance with completing this article. Also, she would like to express her appreciation for her colleagues in the English Department at the University of Fort Hare for their support.

\section{Competing interests}

The authors have declared that no competing interest exists.

\section{Author's contributions}

I declare that I am the sole author of this research article.

\section{Ethical consideration}

This article followed all ethical standards for a research without direct contact with human or animal subjects.

\section{Funding information}

This research received no specific grant from any funding agency in the public, commercial or not-forprofit sectors.

\section{Data availability statement}

Data sharing is not applicable to this article as no new data were created or analysed in this study.

\section{Disclaimer}

The views and opinions expressed in this article are those of the author and do not necessarily reflect the official policy or position of any affiliated agency of the author.

\section{References}

Altick, R., 1973, 'The weaker sex', in R. Altick (ed.), Victorian people and ideas A companion for the modern reader of Victorian literature, pp. 50-59, W. W. Norton \& Co, New York, NY.

Appell, F., 2012, 'Victorian ideals: The influence of society's ideals on victorian relationships', McKendree University Online Journal of Undergraduate Research $18(1)$, viewed n.d., from https://www.mckendree.edu/academics/scholars/ issue18/appell.htm

Bennett, J.M. \& Karras, R.M. (eds.), 2013, The Oxford handbook of women and gender in medieval Europe, Oxford University Press, Oxford.

Berger, J., 1972, Ways of seeing, Penguin, London.

Brittain, A., 1989, Masulinity and power, Basil Blackwell Ltd, Oxford.

Brothers Grimm, 2013a, 'Briar Rose', in Grimm's fairy tales, pp. 28-31, Harper Collins Publishers, London.

Brothers Grimm, 2013b, 'Rapunzel', in Grimm's fairy tales, pp. 71-75, Harper Collins Publishers, London.

Brothers Grimm, 2013c, 'Snow Drop', in Grimm's fairy tales, pp. 143-150, Harper Collins Publishers, London.

Brothers Grimm, 2013d, 'Ashputtel', in Grimm's fairy tales, pp. 164-171, Harper Collins Publishers, London.

Brothers Grimm, 2013e, 'Hansel and Gretel', in Grimm's fairy tales, pp. 88-95, Harper Collins Publishers, London.

Cavendish, R., 2012, 'The publication of Grimm's fairy tales', in History Today 62(12), viewed 20 February 2020, from http://www.historytoday.com/richard-cavendish/ publicationgrimm $\% \mathrm{E} 2 \% 80 \% 99 \mathrm{~s}$-fairy-tales.

Chakraborty, S., 2019, The sleeping beauty wakes up: A feminist interpretation of fairy tales, Penprints Publication, Kolkata.

Chakravorty, S., 2013, 'I am legend - Stereotypes of masculinity in fairy tales', in How happy is their ever after: A few perspectiveson the interior colonisation of women in fairy tales across cultures, pp. 261-294, Jadavpur University, Kolkata.

Dolan, F., 2003, 'Gender and sexuality in early modern Europe', in J. Munns \& P. Richards (eds.), Gender, power and privilege in early modern Europe, pp. 7-20, Pearson Education Limited, London.

Ebel, P., n.d., Rewriting the history of fairy tales: Relocating them within the Parisian Salons of the 1690s, viewed 25 March 2020, from https://www.academia. edu/22213895/Rewriting the_History_of_Fairy_Tales_relocating_them_within the_Parisian_Salons_of_the_1690s.

Gregor, T., 1985, Anxious pleasures: The sexual lives of an amazonian people, University of Chicago Press, Chicago, IL.

Haase, D., 2008, The Greenwood encyclopedia of folktales and fairy tales: A-F, Greenwood Press, London.

Hernandez, I., 2019, Brothers Grimm Fairy tales were never meant for kids, viewed 15 April 2020, from https://www.nationalgeographic.com.au/history/brothersgrimm-fairy-tales-were-never-meant-for-kids.aspx.

Heyn, D., 1992, The erotic silence of the American wife, Signet, New York, NY.

Hoffert, S.D., 2003, History of gender in America: Essays, documents, and articles, Prentice Hall, New York, NY.

Humphrey, M., 2005, Living the hero's quest: Character building through action research, Libraries United, Westport, CT.

Jean, L., 2007, 'Charles Perrault's paradox: How aristocratic fairy tales became synonymous with folklore conservation', Trames 11(61), 276-283.

Karpman, S.B., 2011, 'Fairy tales and script drama analysis', Group Facilitation 11(1), 49-53.

Kuykendal, L.F. \& Strum, B.W., 2007, 'We said feminist fairy tales, not fractured fairy tales! The construction of the feminist fairy tale: Female agency over role reversal', Children and Libraries 1(1), 38-41. 
Lieberman, M.K., 1986, 'Some day my prince will come: Female acculturation through the fairy tale', in J. Zipes (ed.), Don't bet on the prince: Contemporary
feminist fairy tales in North America and England, pp. 185-200, Routledge, New York, NY

Lieberman, M.R., 1972, 'Some day my prince will come: Female acculturation through the fairy tale', College English 34(3), 383-395. https://doi.org/ $10.2307 / 375142$

Mechling, J., 2011, 'Character', in P. Nel \& L. Paul (eds.), Keywords for children's literature, pp. 31-34, New York University Press, New York, NY.

Meyer, J.D., 2015, 'A grim look at Grimm's Fairy tales... and their early 20th century illustrators', The Caxton Club 13(7), 1-7.

Neikirk, A., 2009, 'Happily ever after or what fairy tales teach girls about being women', Hohonu Journal of Academic Writing 7(1), 38-42.

Paradiz, V., 2005, Clever maids: The secret history of the grimm fairy tales, Basic Books, New York, New Brunswick, NJ.

Parsons, L.T., 2004, 'Ella evolving: Cinderella stories and the construction of genderappropriate behaviour', Children's Literature in Education 35(2), 135-154. https:// doi.org/10.1023/B:CLID.0000030223.88357.e8

Pellegrin, M., 2016, 'Female curiosity and male curiosity about women: The views of the Cartesien philospohers', in L. Cottegnies, J. Thompson \& S. Parageau (eds.), Women and curiosity in early modern England and France, pp. 160-174, Brill, Leiden.

Petrie, C., 2000, 'Victorian women expected to be idle and ignorant', in C. Swisher (ed.), Victorian England, pp. 178-187, Greenhaven Press, San Diego, CA.

Robinson, O.W., 2010, Grimm language: Grammar, gender and genuineness in the fairy tale, John Benjamins Publishing Co, Philadelphia, PA.
Rowe, K., 1986, 'To spin a yarn: The female voice in folklore and fairy tale', in R. Bottigheimer (ed.), Fairy tales and society: Illusion, allusion, and paradigm, pp. 53-74, The University of Pennsylvania Press, Philadelphia, PA.

Ruys, J.F. (ed.), 2008, What nature does not teach: Didactic literature in the medieval and early-modern periods, Brepols, Turnhout.

Sagarra, E., 2009, A social history of Germany: 1648-1914, 3rd edn., Transaction Publishers, New Brunswick, NJ.

Sawyer, N., 2014, Feminist outlooks on Disney princess's, James Madison University, Harrisonburg, viewed 01 February 2020, from https://www.academia.edu/ 8627911/Feminist_Outlooks_at_Disney_Princesss.

Smith, W., 2013, 'Happily ever after: The folk tales gathered by the Grimm Brothers not only enchant us; They record the hardships European families endured for centuries', American Scholar 82(1), 10-108.

Tatar, M. (ed.), 1999, 'Introduction: Beauty and the beast', in The classic fairy tales, pp. 25-32, W. W. Norton \& Company, New York, NY.

Thiselton-Dyer, T., 2014. Folk-lore of women, Indo-European Publishing, Los Angeles, CA.

Weitz, R. \& Kwan, S., 2014, The politics of women's bodies: Sexuality, appearance and reality, Oxford University Press, New York, NY.

Yi, S., 2018, 'A feminist reading on sleeping beauty', English Literature and Language Review 4(7), 106-111.

Zipes, J., 1987, 'Fairy tale as myth/myst as fairy tale', Children's Literature 1(1) 107-110. https://doi.org/10.1353/chq.1987.0014

Zipes, J., 2006, Fairy tales and the art of subversion, 2nd edn., Routledge, New York, NY.

Zipes, J., 2012, The irresistible fairy tale: The cultural and social history of a genre, Princeton University Press, Princeton, NJ. 